\title{
Utilization of Rice Husk Waste for Paper Raw Materials as An Arabic Calligraphy Media
}

\author{
Ahmad Zarnuji ${ }^{1}$, Hanif Amrulloh ${ }^{2}$, Isnaini Nur Azizah ${ }^{3}$ \\ ${ }^{1}$ Department of Islamic Education, the Faculty of Tarbiyah, the Islamic Institute of \\ Ma'arif NU Metro Lampung, Metro, Indonesia. \\ ${ }^{2}$ Department of Mathematics Education, the Faculty of Tarbiyah, the Islamic Institute of \\ Ma'arif NU Metro Lampung, Metro, Indonesia. \\ ${ }^{3}$ Department of Early Childhood Islamic Education, the Faculty of Tarbiyah, the Islamic \\ Institute of Ma'arif NU Metro Lampung, Metro, Indonesia. \\ Jl. RA. Kartini, Purwosari, Kecamatan Metro Utara, Kota Metro 34111. \\ hanifamza17@gmail.com
}

\begin{tabular}{|c|c|c|c|c|}
\hline Received & Feb 17th 2019 & Revised & April 9th 2019 & Mav 11 th 2019 \\
\hline
\end{tabular}

\begin{abstract}
Rice busk is an organic waste found in Indonesia as a raw material for paper products. The society has not yet realized that the material could also be a medium of Arabic calligraphy. This research-based community service action aims to introduce the benefits of rice husk as a raw material for making paper. To practice the production of paper from rice husk as the basis for making Arabic calligraphy art, so it is needed to make a business community of paper production from rice busk based on Arabic calligraphy. By using the Asset-Based Community Development method, the community mentoring process is carried out by helping the business community of rice busk paper based on Arabic calligraphy during the production to the marketing process. To control the quality of the art of Arabic calligraphy, the EL-KA Lampung calligraphy community was involved. The result shows that the Arabic calligraphy created by the assisted community has high artistic value with different textures from rice husk paper, then it was created a rice husk paper business community based on Arabic calligraphy.
\end{abstract}

Keyword: Asset-Based Community Development (ABCD), Arabic Calligraphy, Rice Husk Paper, Calligraphy Paper Production

\section{Introduction}

In Indonesia, the paper industry generally uses wood as the primary raw material sourced from increasingly limited natural forests and increasingly high prices. Alternative raw materials are needed to reduce the dependence on the use of wood as a raw material for the paper industry. In general, the primary raw material for paper is cellulose, which obtained from wood or non-wood plants. The high cellulose content in rice husk shows that rice husk has the potential as an alternative raw material for making paper ${ }^{1}$.

Utilization of rice husk into the paper as a calligraphy medium carried out through research-based Community Service activities. This community service activity based on research focused on calligraphy artists in the metro city. Rice husk is an abundant agricultural residue in

\footnotetext{
${ }^{1}$ Muhammad Shoaib Ismail and A.M. Waliuddin, "Effect of Rice Husk Ash on High Strength Concrete," Construction and Building Materials 10, no. 7 (October 1, 1996): 521-526.
} 
Metro City. As an illustration, Metro City Central Bureau of Statistics (BPS) data shows that in 2016 rice production in Metro City reached 35 thousand tons/year'. The results of Widowati's research $^{3}$ show that about $20 \%$ of dry grain is a husk. Thus the potential of the hull in Metro City is around 7000 tons/year. The use of rice husk as a raw material for paper has been studied quite a lot with a variety of materials and methods. Prabawati and Wijaya ${ }^{4}$ made paper made from rice husks and banana tree midribs using a soda process. Ristianingsih, et al. ${ }^{5}$ also made paper based on rice husk and bagasse.

Calligraphy is a written work of art using certain drafting principles. The main thing in calligraphy is beautiful writing; this can include writing in any language, both present or ancient. Islamic architecture of calligraphy developed in the archipelago, many use various kinds of media such as tombs or gravestones, paper, wood, metal, glass, and other materials. Even in its development, calligraphic works emerged through batik media ${ }^{6}$. The development of various styles of calligraphy characterized by the emergence of multiple patterns, forms, and media. Until new trends appear in contemporary calligraphy, such as traditional, figural, expressionist, symbolic and pure abstraction ${ }^{7}$.

In connection with the facts above, this study focuses on increasing the value of art, competence and new creations in the world of calligraphy with rice husk paper media. The purpose of research-based community service activities in the Lampung EL-KA studio Calligraphy are: 1) Introducing the benefits of rice husk that used as paper raw material; 2) practice how to make paper from raw materials of rice husk; 3) applying rice husk paper made as a calligraphy medium; 4) forming a business that is engaged in making paper-based calligraphy art for rice husks; and 5) Assistance to the studio during the production and marketing process.

\footnotetext{
2 BPS Kota Metro, Metro Dalam Angka 2016 (Metro: BPS Kota Metro, 2016).

${ }^{3}$ Sri Widowati, "Use of Side Products of Rice Mills in Support of Agroindustry," Buletin Agrobio 4, no. 1 (2001): 33-38.

${ }^{4}$ Susy Yunita Prabawati and Abdul Gani Wijaya, "Pemanfaatan Sekam Padi Dan Pelepah Pohon Pisang Sebagaibahan Alternatif Pembuat Kertas Berkualitas," Aplikasia, Jurnal Aplikasi Ilmu-Ilmu Agama IX, no. 1 (June 1, 2008): 44-56.

${ }^{5}$ Yuli Ristianingsih, Nelli Angraeni, and Annisa Fitriani, "Proses Pembuatan Kertas Dari Kombinasi Limbah Ampas Tebu Dan Sekam Padi Dengan Proses Soda," CHEMPUBLISH JOURNAL 2, no. 2 (February 6, 2018): 21-32.

${ }^{6}$ Hasan Muarif. Ambary and Jajat Burhanuddin, Menemukan Peradaban: Jejak Arkeologis Dan Historis Islam Indonesia (Ciputat: Logos Wacana Ilmu, 1998).

${ }^{7}$ Ilyas; Al-Faruqi, Isma’il R.; Al-Faruqi, Lois Lamya; Hasan, Atlas Budaya Islam: Menjelajah Khazanah Peradaban Gemilang (Bandung: Penerbit Mizan, 2003).
} 


\section{Methods}

\section{Execution time}

This research-based community service activity starts on April 9, 2018, until November 27,2018

\section{Location and participation of activities}

This research-based community service activity held by the EL-KA Lampung Calligraphy studio, Jl. Kelengkeng II Kelurahan Yosomulyo Metro District Metro City Center. The participants of this activity are calligraphy artists who are members of the studio. The total participants were 50 people.

\section{Materials and tools}

The materials used in this activity are rice husk, caustic soda, water, wood glue, solid glue, Prada, and paint. The tools used are blenders, screen cloths that installed on wooden frames, wooden frames, boards, glue melts, chamois, packet, water pools made of plastic tarps.

\section{Method of Implementation of Activities}

The research-based service delivery method uses the rice husk into the paper as a calligraphy medium using the Asset Based Communities Development (ABCD) approach. ABCD is a community development approach that prioritizes asset utilization and real potential ${ }^{8}$. The stages of service activities are as follows:

\section{Preparing}

This activity begins with a discussion to determine the theme and approach of service that will be carried out in research-based community service. The debate was attended by lecturers who were in the environment of the Ma'arif NU Islamic Institute (IAIMNU) with speakers from the IAIMNU Institute for Development, Research and Community Service (LP3M) represented by LP3M secretary Mr. Habib Sulthon Asnawi, M.H.I. Objects and the target of service are calligraphy artists who are members of the Lampung EL-KA Calligraphy studio in Metro City with the AssetBased Communities Development (ABCD) approach as a community service approach because asset optimization has the advantage of achieving goals with lower costs compared to other methods.

\footnotetext{
${ }^{8}$ John P. Kretzmann et al., Building Communities from the inside out: A Path toward Finding and Mobilizing a Community's Assets (The Asset-Based Community Development Institute, School of Education and Social Policy, Northwestern University, 1993). 


\section{Participatory Program}

This activity aims to collect data in the Lampung calligraphy EL-KA studio, in this activity a document obtained that can be used to analyze the assets owned by the studio. This document covers the founding history and profile of the EL-KA Lampung calligraphy studio. EL-KA Lampung Calligraphy studio is a community of calligraphy artists in Metro City with a pioneer as well as a coach who is Mr. Awang Subianto who founded in 2002 with active members of 50 people with backgrounds in students, santri, students and even scholars. The activities carried out in the studio included routine exercises both to beautify the work and to prepare for the MTQ competition.

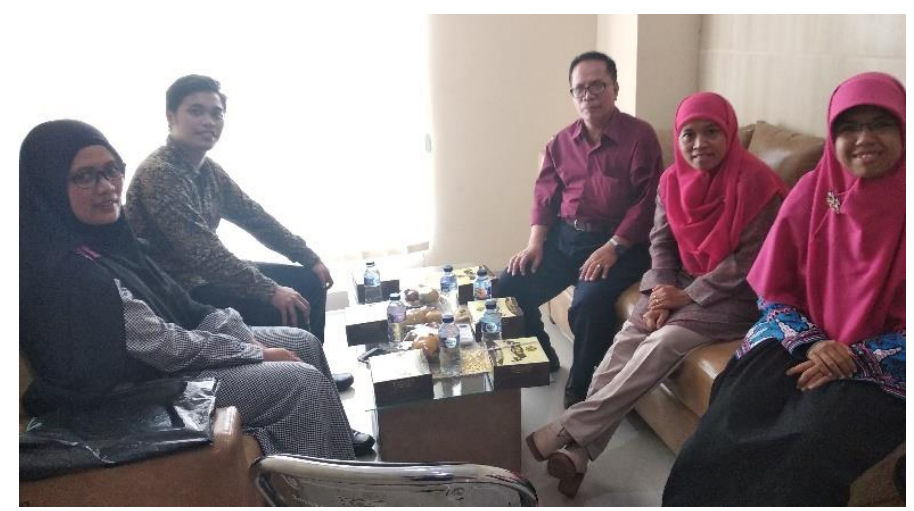

Figure 1. Focus Group Discussion (FGD)

Researchers conducted discussions in the form of Focus Group Discussion (FGD) with several resource persons in the field of chemistry to find alternative data on calligraphy media that can be used to support the creative economy. The discussion attended by Prof. Wasinton Simanjuntak, Ph.D. (Professor of Physics Chemistry, University of Lampung), Dr. Kamisah D Pandiangan, M.Sc. (Chemistry Lecturer at the University of Lampung), Faradilla Syani, M.Sc. (SMK-SMTI teacher), and Endah Pratiwi, M.Sc. (Lecturer at UIN Raden Intan Lampung). The results of this discussion showed that one of the potentials that developed was the use of organic waste-based paper which used as a calligraphy medium. Organic wastes that can be used for making paper include wood waste, rice husk, banana tree trunks, sugarcane pulp, rice stems, water hyacinth.

3. Reinventing Asset

This stage aims to collect assets owned by the Lampung EL-KA Calligraphy studio. These assets include the following:

a. Human Capital

EL-KA Lampung Calligraphy studio has competent members consisting of 50 active members. 
b. Physical Capital

EL-KA Lampung Calligraphy studio has adequate building space and equipment. As shown in Table 1.

Table 1.

Inventory Data of EL-KA Lampung Calligraphy Studio

\begin{tabular}{|l|l|c|}
\hline No. & \multicolumn{1}{|c|}{ Information } & Total \\
\hline 1 & Main rooms $(2 \mathrm{~m} 10 \mathrm{~m})$ & 1 \\
\hline 2 & Lodging rooms $(2 \mathrm{~m} \mathrm{~m} \mathrm{~m})$ & 1 \\
\hline 3 & Oil Paints & 30 \\
\hline 4 & Water Based Paint & 40 \\
\hline 5 & Canvas Fabric & 25 \\
\hline 6 & Plywood Boards & 28 \\
\hline 7 & Brushes Size 3/0 & 6 \\
\hline 8 & Brushes Size 2 & 6 \\
\hline 9 & Brushes Size 4 & 9 \\
\hline 10 & Brushes Size 6 & 5 \\
\hline 11 & Brushes Size 8 & 5 \\
\hline 12 & Brushes Size 12 & \\
\hline
\end{tabular}

c. Environmental Capital

EL-KA Lampung Calligraphy studi located in Metro City with a very conducive environment. Its position is not too close to a noisy highway. Regarding waste that used for paper making, one of the abundant organic wastes in Metro City is rice husk.

\section{Designing}

This stage aims to design activities to be carried out in community service at the EL-KA Lampung Calligraphy studio. Based on the analysis of existing assets, researchers developed community service activities in the form of workshops and training in making paper from rice husks. The researcher experimented first to design paper-making processes.

The first stage is the cleaned rice husk added with a $\mathrm{NaOH}$ solution (Fire Soda) $7 \%$ (w/w). The resulting mixture is then heated to boiling and allowed to stand overnight. Next, the mixture is separated by filtering and then cleaned. Clean rice husk added wood glue with a ratio of 1: 8 (w/w) meaning 1 gram of wood glue for 8 grams of rice husk. The mixture is crushed using a blender to produce pulp. Paper pulp produced, then printed by dissolving in water with a ratio of 1: $3(\mathrm{v} / \mathrm{v})$ and printed using a printing device made of screen cloth and frame. The mold dried to 


\section{ENGAGEMENT}

JurnalPengabdian KepadaMasyarakat

ISSN : 2579-8375 (Print)

ISSN : 2579-8391 (Online)
This work is licensed under a Creative Commons Attribution-ShareAlike 4.0 International License.

dryness.

\section{Communicating}

Researchers established communication with the studio to strengthen the design of workshop activities and training in making rice husk paper as a means to optimize the knowledge and competence of studio members.

\section{Implementing}

The workshop held on October 27, 2018. The workshop speaker was Mr. Prof. Wasinton Simanjuntak, Ph.D. and Mr. Awang Subianto. The material provided is the importance of utilizing waste in Indonesia, the potential use of Rice Husk, the types of writing and techniques in writing calligraphy.

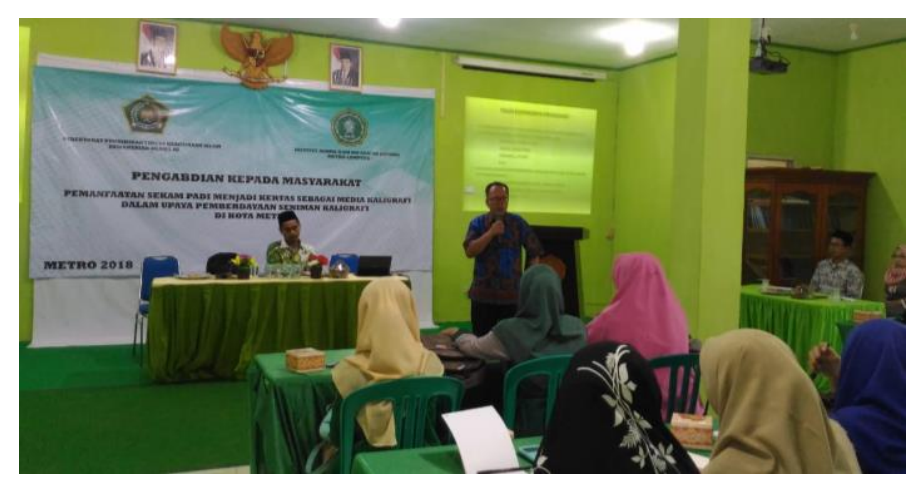

Figure 2. Workshop on the utilization of rice husk into paper as a medium for calligraphy

The next activity was training in making paper from rice husks and continued making calligraphy on the media that produced. This training activity held on the 10th, 11th, 17th and 18th of November 2018 at the Sanggar EL-KA Lampung Calligraphy. This training was guided directly by the research team using a process that obtained previously. Fifty members of the studio attended this training activity.

\section{Evaluating}

In this activity, the research team assessed the performance during the research-based community service in the form of workshops and training. Furthermore, forming a business that is engaged in making paper-based calligraphy techniques for rice husks, and assist in the studio during the production and marketing process. 


\section{ENGAGEMENT}

JurnalPengabdian KepadaMasyarakat

ISSN : 2579-8375 (Print)

ISSN : 2579-8391 (Online)
This work is licensed under a Creative Commons Attribution-ShareAlike 4.0 International License. CC BY SA

\section{Results And Discussion}

\section{Rice Husk Paper Making Process}

The training program for making paper from rice husks held on 10,11 and 17 November 2018 at the Sanggar EL-KA Lampung Calligraphy. This training was guided directly by the research team using a process that obtained previously. Fifty members of the studio attended this training activity.
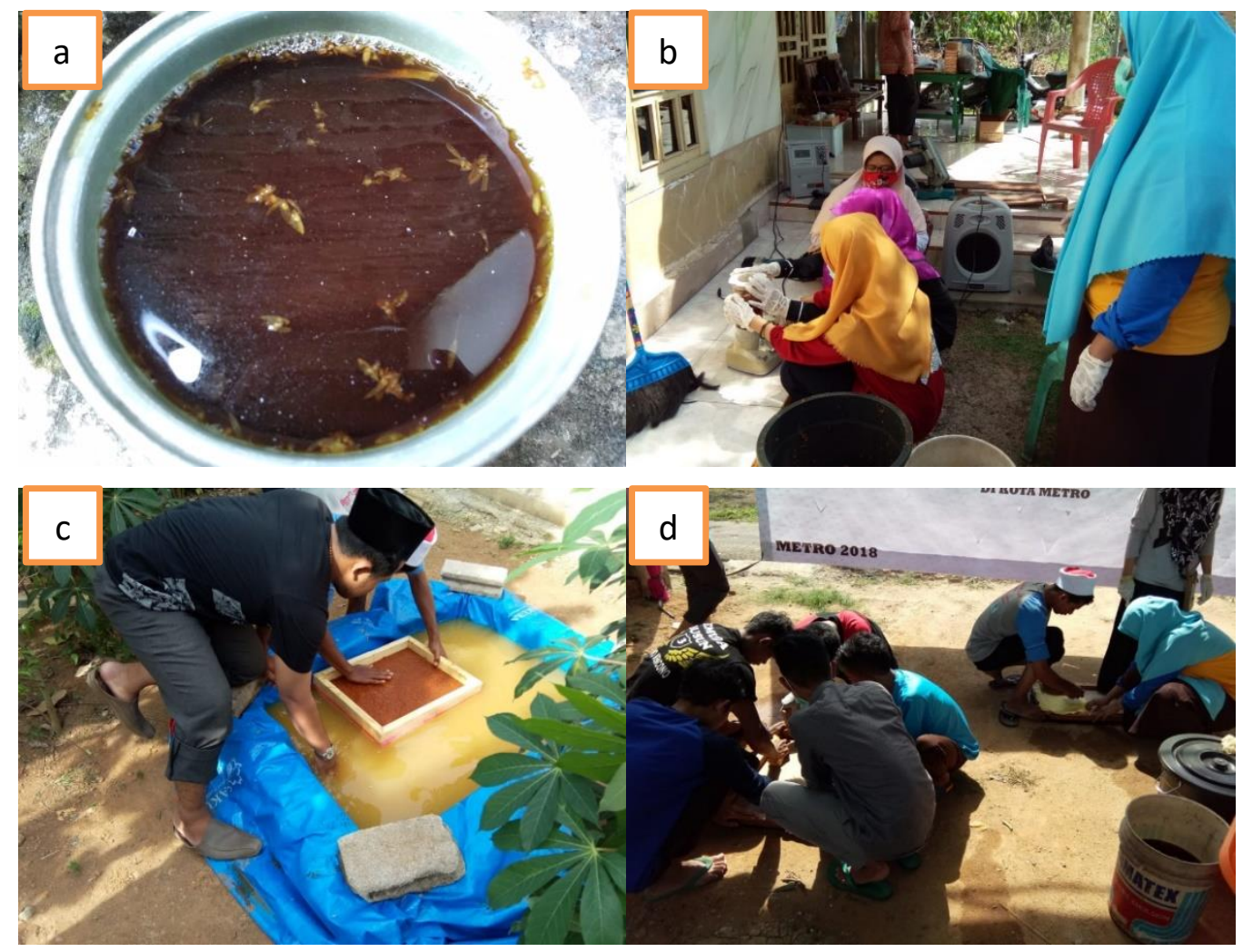

Figure 3. Process of making rice husk paper (a) Cooking husks; (b) destruction of husks (c) printing (d) drying

In this training activity, participants tried to make paper from rice husk directly. Each participant divided into four groups with members varying according to the level of difficulty of the process and each group has their respective duties according to the existing process. The first process is the process of cooking rice husk with $\mathrm{NaOH}$ solution. The second process, the process of mixing silica-free rice husk with wood glue and destroying it. The third process, the process of printing paper pulp into wet paper material and the last method or the fourth process is the process of transferring damp paper from the screen to the moldboard. The papermaking training activity was carried out for three days with the group shifting assignments the following day so that each trainee could understand the process of making paper from rice husk as a whole. 


\section{ENGAGEMENT}

JurnalPengabdian KepadaMasyarakat

ISSN : 2579-8375 (Print)

ISSN : 2579-8391 (Online)
This work is licensed under a Creative Commons Attribution-ShareAlike 4.0 International License. CC BY SA

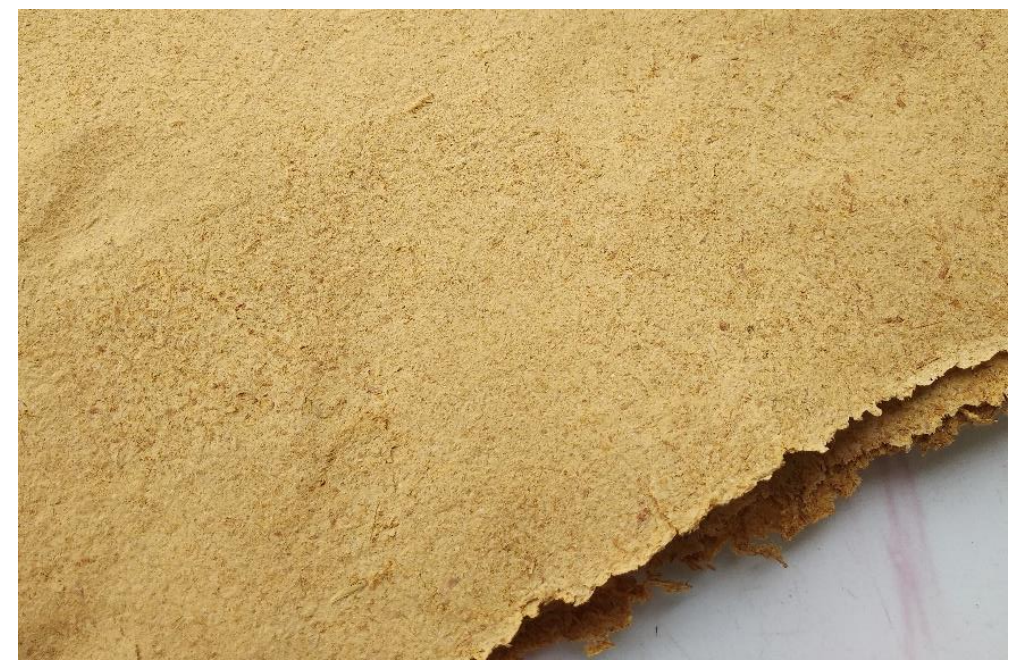

Figure 4. Rice husk paper

\section{Calligraphy Making with Rice Husk Paper}

On the fourth day of the training, the participants received training materials for making calligraphy on the rice husk paper media that produced. The speaker in this training was Mr. Awang Subianto with the training material making calligraphy on rice husk paper media using paint and Prada techniques. In this training, the speaker prepared a calligraphy sketch so that participants only wrote patterns that made on rice husk paper. After the model created, each participant is allowed to give the color the design that has been made with paint or complete the pattern with the Prada technique.

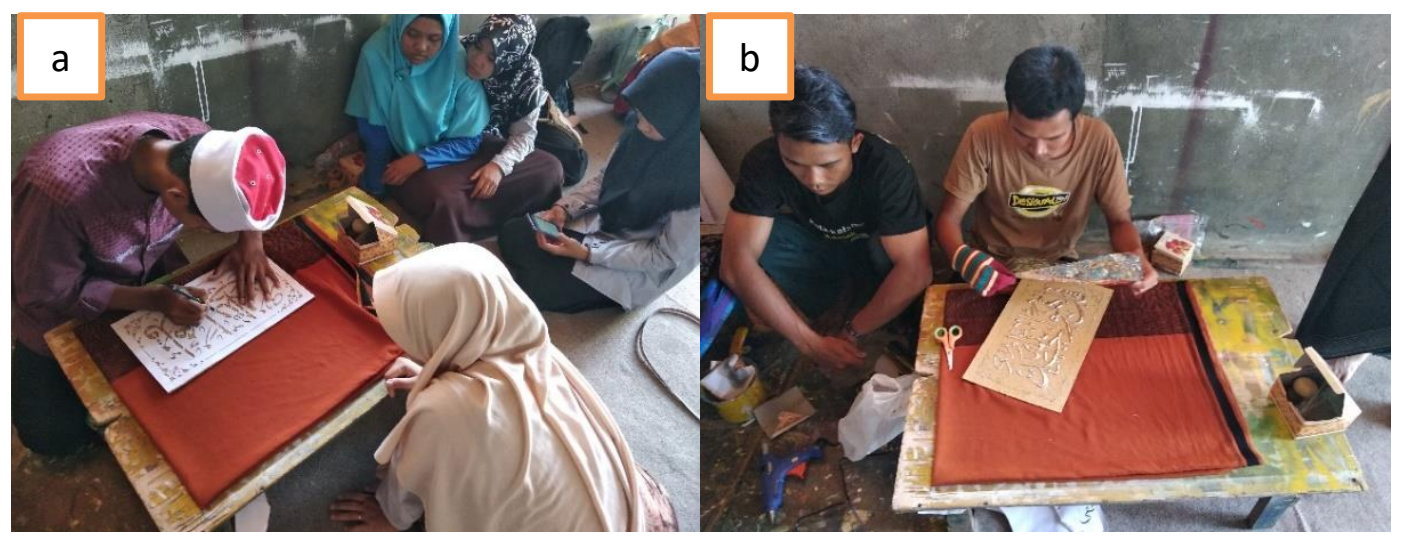

Figure 5. Calligraphy (a) writing the pattern (b) prada technique

The exciting thing about this training is the Prada technical training for making calligraphy on rice husk paper. The choice of this technique, according to the speaker because the method is a technique that is widely used to make calligraphy more attractive and has high economic value. This technique aims to make calligraphy made into arising. First of all, Glue Gun placed on a 


\section{ENGAGEMENT}

JurnalPengabdian KepadaMasyarakat

ISSN : 2579-8375 (Print)

ISSN : 2579-8391 (Online)
This work is licensed under a Creative Commons Attribution-ShareAlike 4.0 International License. CC BY SA

calligraphy pattern that has been made and left to dry. After drying, the glue gun becomes hard and colored using gold and silver colored plastic or commonly called Prada.

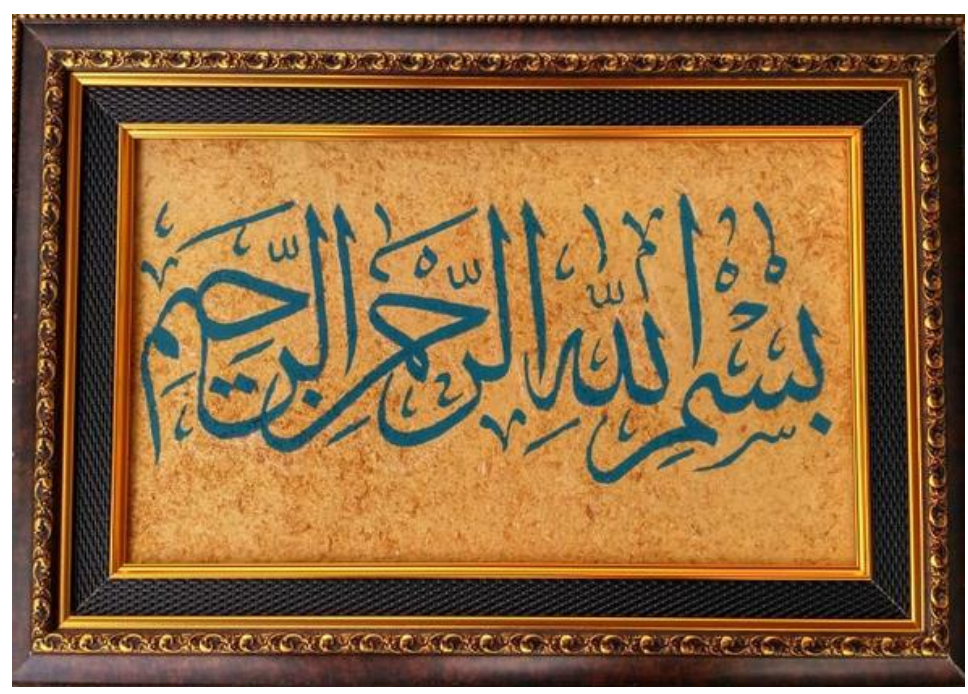

Figure 6. Calligraphy with rice husk paper media

\section{Establishment of Calligraphy Business Group with Rice Husk Paper Media}

Business groups are formed to provide income to the studio especially to members who are interested in producing calligraphy with calligraphy paper media. The EL-KA Lampung studio calligraphy is committed to developing and marketing calligraphy created with rice husk paper media because it can have a positive impact on the progress of the studio. Online stores are made to market the work on a broader scope so that the work of the studio can be known to the broader community (Figure 7). The process of making rice husk paper and calligraphy continues in the studio to prepare if there are consumers who need calligraphy with paper rice husk media.

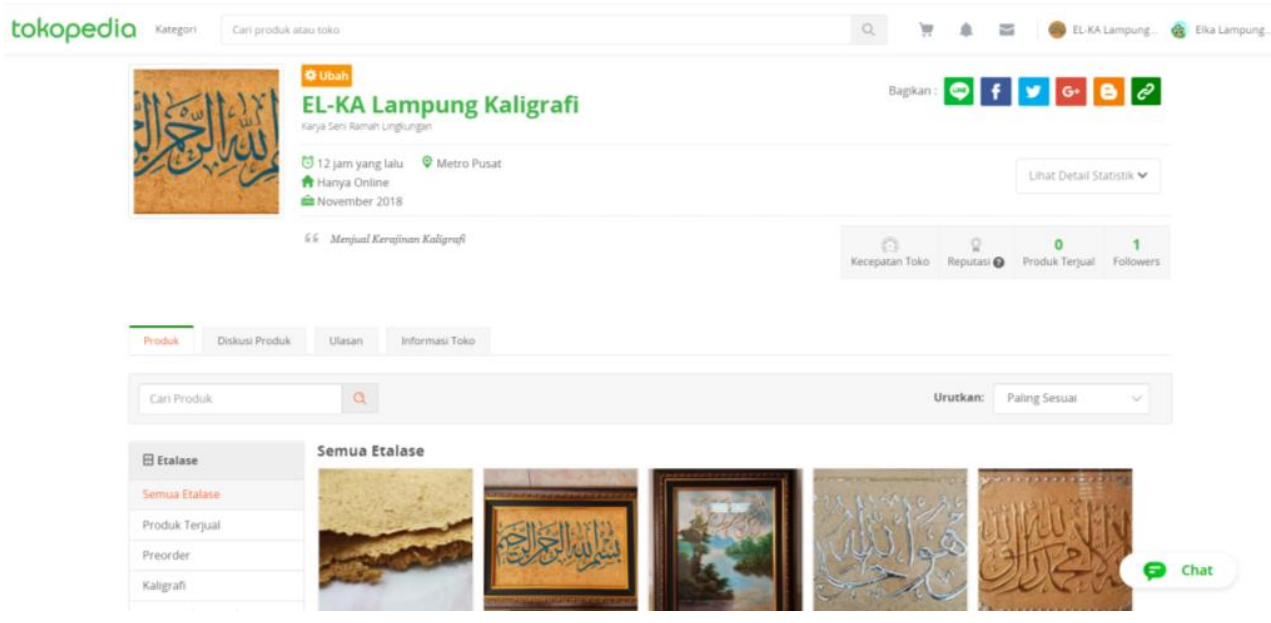

Figure 7. EL-KA Lampung Calligraphy online store

Volume 3, Number 1, Mei 2019|51 


\section{Mentoring of Calligraphy Business Group with Rice Husk Paper Media}

Since the training was carried out and business centers formed, continued assistance sought in terms of the production, packaging and marketing processes. Based on the results of the discussion it was agreed that online stores that were made to keep using the name of the studio and the products sold were rice husk paper and calligraphy with rice husk media.

\section{Obstacles encountered}

The process of transferring paper wet rice husk to the moldboard is a complicated process because if the paper is still wet, it will be challenging to move it to the moldboard. Based on the results of the questionnaire, tools are challenging to use. Drying paper from the screen to the moldboard requires a lot of energy because it pressed so that all the water on the paper comes out. Need a press so that the drying process in the screen becomes more comfortable. The printed board used is recommended to be coated using plastic, because on boards that are not plastic coated when the paper dries it is difficult to separate. Drying paper rice husks under the hot sun can directly damage the quality of rice husk paper. The resulting product will be bumpy which causes the paper to scroll to written. It is recommended to dry paper in the room.

Making calligraphy on paper rice husk can be done quickly. According to Defika, the rice husk paper produced easily written in pencil, pen or ink. However, when coloring calligraphy patterns using paint, rice husk paper absorbs quickly, so it is difficult to stain. The method that done is to coat the paper with wood coating before staining.

\section{Impact of Activities}

The process of implementing community service produces a result that categorized into two forms. First, the results in the way of changes that occurred in the members of the EL-KA Lampung Calligraphy studio were the subject of service. The second is the work in the form of calligraphy craft with rice husk paper.

The first results can be seen in the form of awareness of the members of the studio to utilize the waste around them; the emergence of knowledge to use rice husk to become paper; and an increase in the ability of the studio members to process rice husk into the paper.

The second result is the result of the work produced. Calligraphy with rice husk paper is an effort to improve artistic value, creative industry competency and new creations in the world of calligraphy. This reason shows in the results of the questionnaire, $84 \%$ of respondents said the texture of the paper produced was of high artistic value, suitable and easy to apply with various types of calligraphy works. 
The same thing also expressed by the coach of the studio, Awang Subianto, according to him the paper produced from rice husk had high artistic value. The texture of rice husk on the product needs to be maintained to give a unique impression.

\section{Activity Sustainability Efforts}

The studio wants to develop environmentally friendly calligraphy works not only from paper that comes from rice husk paper but can be combined with other wastes so that it can produce unique works of art. Also, the studio also wants paper making not only from rice husks but from other scraps such as banana tree trunks and sugarcane pulp for a variety of calligraphy media. However, for the time being, the main target after this activity is the continuity of the calligraphy business with rice husk paper media can continue.

\section{Conclusion}

Research-Based Community Service Activities Using Rice Husk into Paper as a Calligraphy Media was carried out in the form of workshops and training in the Metro City Calligraphy ELKA Studio, attended by 50 participants who joined as members in the studio. Research-Based Community Service Results conducted at Sanggar EL-KA Lampung Calligraphy in the form of increasing the knowledge and competence of calligraphy artists in Metro City utilizing rice husks into the paper that used as a calligraphy medium. Calligraphy made from paper made from rice husk can increase the value of the calligraphy art produced. The calligraphy created is a new creation in the world of calligraphy, which used for the development of creative industries.

\section{Acknowledgments}

Thank you to the Directorate of Islamic Religious Higher Education (Diktis) of the Directorate General of Islamic Education of the Ministry of Religion of the Republic of Indonesia who has provided funding for Community Service Research Based on Research Aid in 2018. Thank you also to the dedicated Metro City Sanggar EL-KA Lampung Kaligrafi in developing the use of rice husk into the paper as a medium for calligraphy.

Gratefully thanks to Mr. Prof. Wasinton Simanjuntak, Ph.D.; Mrs. Dr. Kamisah D Pandiangan, M.Si.; Mrs. Faradilla Syani, M.Si.; and Mrs. Endah Pratiwi, M.Si. for your knowledge and input during the dedication process. 


\section{References}

Al-Faruqi, Isma'il R.; Al-Faruqi, Lois Lamya; Hasan, Ilyas; Atlas Budaya Islam: Menjelajah Khazanah Peradaban Gemilang. Bandung: Penerbit Mizan, 2003.

Ambary, Hasan Muarif., and Jajat Burhanuddin. Menemukan Peradaban : Jejak Arkeologis Dan Historis Islam Indonesia. Ciputat: Logos Wacana Ilmu, 1998.

Ismail, Muhammad Shoaib, and A.M. Waliuddin. "Effect of Rice Husk Ash on High Strength Concrete." Construction and Building Materials 10, no. 7 (October 1, 1996): 521-526.

Kretzmann, John P., John McKnight, Ill.). Institute for Policy Research. Northwestern University (Evanston, and Ill.). Asset-Based Community Development Institute. Northwestern University (Evanston. Building Communities from the inside out: A Path toward Finding and Mobilizing a Community's Assets. The Asset-Based Community Development Institute, School of Education and Social Policy, Northwestern University, 1993.

Metro, BPS Kota. Metro Dalam Angka 2016. Metro: BPS Kota Metro, 2016.

Ristianingsih, Yuli, Nelli Angraeni, and Annisa Fitriani. "Proses Pembuatan Kertas Dari Kombinasi Limbah Ampas Tebu Dan Sekam Padi Dengan Proses Soda." CHEMPUBLISH JOURNAL 2, no. 2 (February 6, 2018): 21-32.

Sri Widowati. "Use of Side Products of Rice Mills in Support of Agroindustry." Buletin Agrobio 4, no. 1 (2001): 33-38.

Susy Yunita Prabawati, and Abdul Gani Wijaya. "Pemanfaatan Sekam Padi Dan Pelepah Pohon Pisang Sebagaibahan Alternatif Pembuat Kertas Berkualitas." Aplikasia, Jurnal Aplikasi Ilmu-Imu Agama IX, no. 1 (June 1, 2008): 44-56. 